\title{
Studies of correlation between progression of coronary artery disease, as assessed by coronary arteriography, left ventricular end-diastolic pressure, ejection fraction, and employability
}

\author{
SIGURD NITTER-HAUGE, KJELL NOREIK, SVEIN SIMONSEN, \\ OLE STORSTEIN, TONE BJØRBAEK, AND AASTA STEEN
}

From Medical Department B, University Hospital, Rikshospitalet and Institute of Social Medicine, University of Oslo, Norway

The occupational status of a group of 100 male patients, 35 to 68 years of age, with chronic ischaemic heart disease was studied, and related to the severity and distribution of coronary artery stenosis seen on the arteriograms and to left ventricular function. In this series of patients 31 per cent were working, 31 per cent were recorded as temporarily sick, and 38 per cent as permanently disabled.

It appears that while the type of previous occupation and physical activity associated with the job were of importance, there was no correlation between employability on the one hand and severity and distribution of coronary artery disease on the other.

'Blue-collar' workers had a higher rate of unemployment than those in 'white collar' occupations, but this could not be explained by differences in severity of coronary artery disease.

The first report on the resumption of work in patients with ischaemic heart disease was published in 1930 (Conner and Holt). Since then, the re-employment of patients with coronary artery disease has been discussed frequently and several variables have been used with the view to predicting the possibility of occupational rehabilitation. According to Garrity (1973), these variables may be classified into three categories: sociodemographic, sociopsychological, and medical. Most previous studies have been undertaken with the two former categories as their central theme. The re-employment of patients with ischaemic heart disease must also depend on the severity of coronary artery disease itself, though an extensive review of the published material on cardiac rehabilitation indicates that very little research has been done in this field. This is particularly true in the time of the chronic phase, when many patients are dependent on social security systems.

In the present study, attention has been focused upon the correlation between the working status and objective signs of disease, as progression of disease seen in coronary arteriograms, together with data for left ventricular function.

Received for publication 19 January 1977

\section{Patients and methods}

The study population was a group of 100 male patients, 35 to 68 years in age (mean $=52.7$ years) who had chronic, stable, and arteriographically documented coronary artery disease. They were referred to us for diagnostic evaluation before aortocoronary vein bypass surgery. According to the working status at admission, the patients were divided into 3 subgroups.

Actually working, i.e. all patients who at the time of admission were working more than 4 hours a day.

Temporary disability, i.e. those not working at the time of admission, but where their condition was assumed to be temporary ('temporary sickleave').

Permanent disability, i.e. those not working at the time of admission, and where their condition was assumed to be permanent.

On admission, the patients were interviewed by professional social workers (T.B. and A.S.). The patients were classified according to their occupational status. The largest occupational group, 'blue collar' workers, consists of all skilled and unskilled 
manual labourers. The second group, 'white collar' workers, was composed of managerial, middle, and lower status 'white collar' occupations and included also self-employed businessmen and professionals. The sociomedical examination also included an assessment of physical and psychological stress involved in the work, based on the patients' own judgment. According to this, the patients were classified into three categories: heavy, moderate, and light physical strain, and severe, moderate, and no psychological stress.

Selective coronary arteriography was performed by the technique of Judkins (1967). The three main coronary arteries-the anterior descending branch and the circumflex branch of the left coronary artery and the right coronary artery were identified and evaluated separately. Each artery was graded individually according to the following scoring system. 0, no arteriographic abnormalities; 1 , localised narrowing estimated to be more than 10 per cent but less than 75 per cent of the luminal cross-section area; 2 , narrowing(s) estimated to be more than 75 per cent but less than 90 per cent; 3 , total occlusion without any filling of the distal segment from the proximal portion. The 3 scores together gave a total score which represented the overall obstructive disease for all 3 arteries of the heart. Left ventriculography was performed in the right anterior oblique plane. The contrast material used was Isopaque Coronar (metrizoate meglumine/ $\mathrm{Na} / \mathrm{Ca}(58 / 9 / 1) 370 \mathrm{mg} \mathrm{J} / \mathrm{ml})$.

Left ventricular pressures were measured before and 2 minutes after left ventriculography. Pressures were recorded with Elema Schønander equipment (Transducer EMT 35 and Mingograf 81). The baseline was at the 4 th intercostal space on the anterior axillary line. The end diastolic pressure was measured at the intercept between the ' $a$ ' wave and the rapid ventricular upstroke.

The films were analysed directly on a Tagarno projector. The ejection fraction was measured by outlining the internal contour of the left ventricle in systole and diastole; the formula given by Arbogast et al. (1973) was used. The validity of this mathematical model in man has been shown by Davila and Sanmarco (1966).

The data were processed at the hospital computer centre. The $P$ value indicated in the Tables refers to the significance level of the classical $\chi^{2}$ test of independence between two categorical variables.

\section{Results}

At admission, 31 patients were recorded as working while 31 were recorded as temporarily sick and 38 as permanently disabled. Table 1 shows the inter- relation between working status and age, duration of symptoms, occupation, physical strain, and psychological stress in previous occupation. In these series of men under 68 years, age per se apparently was not related to working status. Though there was no significant correlation between working status and duration of symptoms, the data indicate a tendency towards a higher rate of unemployment among those with the longest duration of symptoms. More obvious, the data show that working status was closely dependent on the type of previous employment and the physical strain associated with it. 'Blue collar' workers had a higher rate of unemployment than 'white collar' workers or employers. Similarly, those with jobs containing heavy or moderate physical stress had a higher rate of unemployment than those with less physically stressful occupations. On the other hand, the psychological stress involved in a job was apparently unrelated to work status.

Analysis of data obtained from the coronary arteriograms showed that no correlation seemed to exist between work status on the one hand and severity of coronary artery disease on the other.

Table 1 Relations between working status and age, duration of symptoms, occupation, physical strain, and psychological stress in previous occupation

\begin{tabular}{|c|c|c|c|c|}
\hline & $\begin{array}{l}\text { Employed at } \\
\text { time of } \\
\text { examination } \\
(31) \\
\%\end{array}$ & $\begin{array}{l}\text { Temporarily } \\
\text { sick } \\
(31) \\
\%\end{array}$ & $\begin{array}{l}\text { Permanently } \\
\text { disabled } \\
(38) \\
\%\end{array}$ & Total \\
\hline \multicolumn{5}{|l|}{ Age (y) } \\
\hline $30-49$ & 50 & 0 & 50 & 6 \\
\hline $40-49$ & 26 & 30 & 43 & 23 \\
\hline $50-59$ & 39 & 29 & 37 & 52 \\
\hline $60-69$ & 21 & 47 & 32 & $\begin{array}{l}19 \\
P: 0.43\end{array}$ \\
\hline \multicolumn{5}{|l|}{$\begin{array}{l}\text { Duration of } \\
\text { symptoms }(y)\end{array}$} \\
\hline$<1$ & 47 & 47 & 7 & 15 \\
\hline $1-5$ & 27 & 35 & 38 & 52 \\
\hline$>5$ & 30 & 18 & 52 & $\begin{array}{l}33 \\
P: 0.09\end{array}$ \\
\hline \multicolumn{5}{|l|}{$\begin{array}{l}\text { Occupational } \\
\text { category }\end{array}$} \\
\hline Blue collar & 15 & 36 & 48 & 66 \\
\hline White collar & 62 & 21 & 17 & $\begin{array}{l}34 \\
P: 0.01\end{array}$ \\
\hline \multicolumn{5}{|c|}{$\begin{array}{l}\text { Physical strain } \\
\text { involved in previous } \\
\text { work }\end{array}$} \\
\hline Heavy & 19 & 29 & 52 & 42 \\
\hline Moderate & 24 & 41 & 35 & 37 \\
\hline Easy & 65 & 20 & 15 & $\begin{array}{l}21 \\
P: 0.01\end{array}$ \\
\hline \multicolumn{5}{|c|}{$\begin{array}{l}\text { Psychological stress } \\
\text { involved in previous } \\
\text { work }\end{array}$} \\
\hline $\begin{array}{l}\text { Severe } \\
\text { Moderate }\end{array}$ & $\begin{array}{l}36 \\
31\end{array}$ & $\begin{array}{l}29 \\
44\end{array}$ & $\begin{array}{l}36 \\
26\end{array}$ & $\begin{array}{l}28 \\
39\end{array}$ \\
\hline None & 27 & 18 & 55 & $\begin{array}{l}33 \\
P: 0 \cdot 11\end{array}$ \\
\hline
\end{tabular}


The results were the same whether the scores of each main coronary artery were analysed separately or the total scores were used (Table 2). Analysis of the haemodynamic pattern and work status showed that the left ventricular function estimated from the ejection fraction and the left ventricular end diastolic pressures before and after ventriculography were the same when working and nonworking patients were compared (Table 3 ).

In the present study 'blue collar' workers had a higher rate of unemployment than those in 'white collar' occupations. 'Blue collar' workers had the same age distribution as the 'white collar' group, they were more often engaged in heavy physical work, and they more often belonged to lower social strata than those from 'white collar' occupations. No differences were found between 'white' and 'blue collar' groups in psychological stress associated with their previous work (Table 4). There was no apparent difference between the groups in relation to the severity of coronary artery disease present (Table 5).

Table 2 Relations between working status and scores in anterior descending artery ( $L A D)$, circumflex artery, and right coronary artery

\begin{tabular}{llll}
\hline $\begin{array}{l}\text { Coronary } \\
\text { arteriogram }\end{array}$ & $\begin{array}{l}\text { Employed at at } \\
\text { time of } \\
\text { examination }\end{array}$ & $\begin{array}{l}\text { Temporarily } \\
\text { sick }\end{array}$ & $\begin{array}{l}\text { Permanently Total } \\
\text { disabled }\end{array}$ \\
& $(31)$ & $(31)$ & $(38)$ \\
& $\%$ & $\%$ & $\%$ \\
\hline
\end{tabular}

\begin{tabular}{|c|c|c|c|c|}
\hline \multicolumn{5}{|l|}{$\begin{array}{l}\text { Score in anterior } \\
\text { descending artery } \\
(L A D)\end{array}$} \\
\hline Open & 29 & 47 & 24 & 17 \\
\hline $10-75$ per cent & 18 & 35 & 47 & 17 \\
\hline $75-90$ per cent & 42 & 27 & 30 & \\
\hline Occluded & 27 & 24 & 48 & $\begin{array}{l}33 \\
\text { P: } 0 \cdot 18\end{array}$ \\
\hline \multicolumn{5}{|l|}{$\begin{array}{l}\text { Score in circumflex } \\
\text { artery }\end{array}$} \\
\hline Open & 31 & 31 & 38 & 32 \\
\hline $10-75$ per cent & 18 & 36 & 46 & 28 \\
\hline $75-90$ per cent & 39 & 26 & 35 & 31 \\
\hline Occluded & 44 & 33 & 22 & $\begin{array}{c}9 \\
P: 0.73\end{array}$ \\
\hline \multicolumn{5}{|l|}{$\begin{array}{l}\text { Score in right } \\
\text { coronary artery }\end{array}$} \\
\hline Open & 38 & 29 & 33 & 21 \\
\hline $10-75$ per cent & 17 & 67 & 17 & \\
\hline $75-90$ per cent & 28 & 34 & 38 & 32 \\
\hline Occluded & 34 & 17 & 49 & $\begin{array}{l}35 \\
P: 0 \cdot 13\end{array}$ \\
\hline \multicolumn{5}{|l|}{ Total score } \\
\hline $1-5$ & 27 & 45 & 27 & 11 \\
\hline $6-8$ & 31 & 31 & 38 & 13 \\
\hline $9-11$ & 30 & 39 & 30 & \\
\hline 12 and more & 32 & 25 & 43 & 53 \\
\hline & & & & P: 0.78 \\
\hline
\end{tabular}

Table 3 Relations between working status and left ventricular function estimated from ejection fraction and left ventricular end diastolic pressures (LVED) before and after ventriculography

\begin{tabular}{|c|c|c|c|c|}
\hline & $\begin{array}{l}\text { Employed at } \\
\text { time of } \\
\text { examination } \\
(31) \\
\%\end{array}$ & $\begin{array}{l}\text { Temporarily } \\
\text { sick } \\
(31) \\
\%\end{array}$ & $\begin{array}{l}\begin{array}{l}\text { Permanently } \\
\text { disabled }\end{array} \\
(38) \\
\%\end{array}$ & Total \\
\hline $\begin{array}{l}\text { Ejection fraction } \\
>50 \text { per cent } \\
<50 \text { per cent }\end{array}$ & $\begin{array}{l}31 \\
31\end{array}$ & $\begin{array}{l}33 \\
19\end{array}$ & $\begin{array}{l}36 \\
50\end{array}$ & $\begin{array}{l}84 \\
16 \\
\text { P: } 0.44\end{array}$ \\
\hline $\begin{array}{l}\text { LVED pressure } \\
\text { before } \\
\text { ventriculography } \\
12 \mathrm{mmHg} \\
12-24 \mathrm{mmHg} \\
25 \mathrm{mmHg} \text { or } \\
\text { more } \\
\text { LVED pressure } \\
\text { after ventriculogra }\end{array}$ & $\begin{array}{l}31 \\
28 \\
50\end{array}$ & $\begin{array}{l}28 \\
37 \\
10\end{array}$ & $\begin{array}{l}42 \\
35 \\
40\end{array}$ & $\begin{array}{l}36 \\
54 \\
10 \\
\text { P: } 0 \cdot 44\end{array}$ \\
\hline $\begin{array}{l}<12 \mathrm{mmHg} \\
12-24 \mathrm{mmHg} \\
25 \mathrm{mmHg} \text { or } \\
\text { more }\end{array}$ & $\begin{array}{l}20 \\
30 \\
38\end{array}$ & $\begin{array}{l}40 \\
30 \\
28\end{array}$ & $\begin{array}{l}40 \\
39 \\
34\end{array}$ & $\begin{array}{l}15 \\
56 \\
29 \\
\text { P: } 0 \cdot 79\end{array}$ \\
\hline
\end{tabular}

Table 4 Relations between type of previous occupation and age, physical strain, psychological stress involved in previous work, and social strata

\begin{tabular}{|c|c|c|}
\hline & $\begin{array}{l}\text { Manual labourers } \\
\text { ('blue collar') } \\
(66) \\
\%\end{array}$ & $\begin{array}{l}\text { Employees and } \\
\text { owners and } \\
\text { managers ('white } \\
\text { collar') } \\
(34) \\
\%\end{array}$ \\
\hline \multicolumn{3}{|l|}{ Age (y) } \\
\hline $30-39$ & 6 & 6 \\
\hline $40-49$ & 20 & 23 \\
\hline $50-59$ & 55 & 52 \\
\hline $60-69$ & 20 & 19 \\
\hline \multirow[t]{2}{*}{ Total } & 101 & 100 \\
\hline & & P: 0.10 \\
\hline \multicolumn{3}{|c|}{$\begin{array}{l}\text { Physical strain involved in } \\
\text { previous work }\end{array}$} \\
\hline Heavy & 50 & 42 \\
\hline Moderate & 38 & 37 \\
\hline Easy & 12 & 21 \\
\hline \multirow[t]{2}{*}{ Total } & 100 & 100 \\
\hline & & $P: 0.01$ \\
\hline \multicolumn{3}{|c|}{$\begin{array}{l}\text { Psychological stress involved in } \\
\text { previous work }\end{array}$} \\
\hline Severe & 21 & 28 \\
\hline Moderate & 41 & 39 \\
\hline None & 38 & 33 \\
\hline Total & 100 & 100 \\
\hline & & P: 0.44 \\
\hline \multicolumn{3}{|l|}{ Social strata } \\
\hline Above average & 3 & 16 \\
\hline Average & 91 & 79 \\
\hline Below average & 6 & 5 \\
\hline \multirow[t]{2}{*}{ Total } & 100 & 100 \\
\hline & & $P: 0.00$ \\
\hline
\end{tabular}


Table 5 Relations between type of previous occupation and total coronary artery score

\begin{tabular}{lll}
\hline Coronary arteriogram & $\begin{array}{l}\text { Manual labourers } \\
\text { Employees and } \\
\text { owners and managers } \\
(66)\end{array}$ & $\begin{array}{l}(34) \\
\%\end{array}$ \\
\hline Total score & $\%$ & \\
$1-5$ & & 11 \\
$6-8$ & 9 & 13 \\
$9-11$ & 14 & 23 \\
12 and more & 21 & 53 \\
Total & 56 & 100 \\
& 100 & $\mathrm{P}: 0.74$ \\
\hline
\end{tabular}

\section{Discussion}

The employability of patients with ischaemic heart disease has previously been based mostly on studies carried out after an acute myocardial infarct and from the point of view of number of infarctions, clinical heart failure, duration of sick leave, age, sex, marital status, and previous occupation. The present research is based on patients with chronic ischaemic heart disease of whom the majority had been dependent on social security systems for a long time, and grew out of the awareness that the work status in such patients should be related to the extent of structural involvement seen from the coronary arteriograms and patterns of left ventricular function.

Our results indicate that unemployment in patients with chronic ischaemic heart disease cannot be explained by the apparent severity of the coronary artery disease. The extent of structural changes seen on the coronary arteriograms as well as various tests of left ventricular performance were found to be identical when the patients working full time were compared with those recorded as temporarily sick or permanently disabled. The employability of patients with chronic ischaemic heart disease seems to be burdened with a discrepancy between the employability on the one hand and the objective indices of heart disease on the other. This conclusion is in accordance with other investigations, studying rehabilitation after heart valve operations (Nitter-Hauge et al., 1976).

The tendency observed in the present study parallels that seen in cases of patients who abandon work after an acute myocardial infarct (Malmcrona et al., 1962; Sharland, 1964; Shapiro et al., 1972; Vuopala, 1972). The type of work done previously by the patients seems to be a major determinant in deciding whether they will be able to return to it. The prospects are usually less favourable for 'blue collar' than for 'white collar' workers. It is also known that after an acute myocardial infarct, the relative discrepancy in occupational prognosis by severity of the illness diminishes with time and is relatively small after one or two years (Weinblatt $e t$ al., 1966; Kjøller, 1976). It is interesting to note that according to Kjøller (1976) only 37 per cent of patients unemployed after a myocardial infarct gave cardiac symptoms as the main factor why they had not gone back to work. It was claimed equally often that work was abandoned voluntarily or on account of an illness other than heart disease. In addition, in 19 per cent of the cases the main reason was that a general practitioner in the course of a routine check-up had advised the patients to abandon work. The influence of casual advice from general practitioners, the reluctance of employers to allow 'blue collar' workers to resume their previous work, the possible inhibiting role of workmen's compensation rulings and disability pensions, and the relative inflexibility of some 'blue collar' jobs in offering less strenuous work routines could also contribute to the differences observed in employability in the present study.

Because of methodological problems, the occupational circumstances of the present patients cannot be fully assessed. From the arteriographic and haemodynamic findings, however, it is tempting to suggest that many of those recorded as unemployed should be fit for some form of work.

More extensive examinations including coronary arteriography and evaluation of the type of work should be used before definite conclusions regarding working ability are made.

This study was supported by grants from The Norwegian Council on Cardiovascular Diseases, Oslo, Norway.

\section{References}

Arbogast, R., Solignac, A., and Bourassa, M. G. (1973). Influence of aortocoronary saphenous vein bypass surgery on left ventricular volumes and ejection fraction. American fournal of Medicine, 54, 290-296.

Conner, L. S., and Holt, E. (1930). The subsequent course and prognosis in coronary thrombosis. An analysis of 287 cases. American Heart fournal, 5, 705-719.

Davila, J. C., and Sanmarco, M. E. (1966). An analysis of the fit of mathematical models applicable to the measurement of left ventricle volume. American fournal of Cardiology, 18,31 .

Garrity, T. F. (1973). Vocational adjustment after first myocardial infarction; comparative assessment of several variables suggested in the literature. Social Science and Medicine, 7, 705-717.

Judkins, M. P. (1967). Selective coronary arteriography, Part I. A percutaneous transfemoral technic. Radiology, 89, 815-824.

Kjøller, E. (1976). Resumption of work after acute myocardial infarction. Acta Medica Scandinavica, 199, 379-385. 
Malmcrona, R., Söderholm, B., Björntorp, P., Thulesius, O., and Heyman, F. (1962). Myocardial infarction in the younger age groups. Acta Medica Scandinavica, 171, 59-67.

Nitter-Hauge, S., Frøysaker, T., and Hall, K. V. (1976). Reemployment related to functional and haemodynamic changes after aortic or mitral valve replacement. Annales chirurgiae et gynaecologiae Fenniae, 65, 124-131.

Shapiro, S., Weinblatt, E., and Frank, C. W. (1972). Return to work after first myocardial infarction. Archives of Environmental Health, 24, 17-26.

Sharland, D. E. (1964). Ability of men to return to work after cardiac infarction. British Medical fournal, 2, 718-720.

Vuopala, U. (1972). Resumption of work after myocardial infarction in Northern Finland. Acta Medica Scandinavica, Suppl. 530.

Weinblatt, E., Shapiro, S., Frank, C. W., and Sager, R. V. (1966). Return to work and work status following first myocardial infarction. American Fournal of Public Health, 56, 169-185.

Requests for reprints to Dr. Sigurd Nitter-Hauge, Medical Department B, Rikshospitalet, National Hospital of Norway, University Hospital, Oslo 1, Norway. 